\title{
Biochemical Analysis of Root, Stem and Leaf of the Soyabean Seedling of 15 Days Grown in Plain and Amended Soil
}

\author{
Kumar Vimal ${ }^{1}$, Anand Kishor ${ }^{2}$ \\ ${ }^{1,2}$ University department of Botany, Veer Kunwar Singh University Ara (Bihar) India
}

\begin{abstract}
A scheme was undertaken with a view to explore the possibility of improving productivity of Soyabean (Glycine Max (L) Merr) variety Indira Soya. The Study was focused on the amendment of soil with vermicompost, neem cake and urea. Biochemical analysis includes chlorophyll contents; protein content, sugar content and electrical conductivity were investigates.
\end{abstract}

Keywords: Indira soya, amendment soil, Nutritional value

\section{Introduction}

Soyabean were a crucial crop in eastern Asia long before written records. They remains a major crop in china, japan and Mexico prior to fermented products such as a soy, sauce, tempeh, natto and miso, soya was conspire sacred for its use in crop rotation as a method of fixing nitrogen. Soyabean did not become an important crop outside of Asia until about 1910. In America soya was considered an industrial products only and was not used as food prior to the 1920s. Soyabean posses a very high nutritional value. It contains about $20 \%$ oil, and 405 high quality proteins. Protein is rich in valuable amino acid lysine $5 \%$ in which most of the cereals are deficient. In addition, it contains a good amount of minerals, salt and vitamin(thiamine and riboflavin) and its sprouting grains contains a considerable amount of vitamin c, vitamin A is present in the form of precursor carotene, which is converted into vitamin A in the intestine. Soyabean are considered by many agencies to be a source of complete protein (Henkel 2000). The gold standard for measuring protein quality, since 1990 is the protein digestibility corrected amino acid score (PDCAAS) and by this criterion soya protein. The nutritional equivalent of meat, eggs and casein for human growth and health. Derbyshire et al. (1976), Daniclsson (1949) and Wolf (2012) suggested that soya protein is essentially identical to that of other legume seeds. Symolon et al. (2004) investigated that consumption of soya may also reduce the risk of colon cancer possible due to the presence of sphingolipids.

\section{Material and Method}

The seeds of Soyabean (Glycine max (L) Merr) variety Indira soy 9 were collected from Saraswati beez bhandar Ara (Bhojpur) Bihar.

\section{Use of Glasswares}

All the Glassware's used were made of corning or Borosil brand such as Petri dishes, Culture tubes, conical flasks, burettes, funnels and measuring cylinder.

\section{Use of Water}

For ordinary purpose such as washing, cleansing the glassware's and other apparatus etc. tap water was used and distilled water used for prepare mixture.

\section{Sterilization}

Glassware's were oven sterilized at 160 degree Celsius for 4 hrs.Afterwrapping in the newspaper. Water filter paper and towels were sterilized in autoclave at 15 psi for 15-20 minutes.

\section{Amendment of Soil}

Plain soil was collected from the farm land and dried in sun for one week. Plain soil was mixed with vermicompost in the ratio of $1: 1$ and plain soil was mixed with neem cake in the ratio of 3:1 while urea was mixed with plain soil at the rate of $2.5 \mathrm{~g}$ per kilogram.

\section{Determination of Electrical Conductivity}

2 gram each sample of root, stem and leaf was weighed and extracted in $20 \mathrm{ml}$ of conductivity water by the help of mortar and pastle separately. $10 \mathrm{ml}$ of plant extract was taken.

\section{Determination of Protein Content}

Protein contents in the plant extract (root, stem, leaf) were measured by Biuret assay method.

\section{Determination of Sugar Content}

Pentose and Hexose sugars in the plant extract were measured calorimetrically at 480 and $490 \mathrm{~nm}$ respectively using phenol-sulphuric acid method (Dubois et al.-1951).

\section{Determination of Chlorophyll}

$100 \mathrm{mg}$ of leaf was taken and chlorophyll was extracted in diffused and deem light with $10 \mathrm{ml}$ of 805 acetone using small glass mortar and pestle. The extracts were pooled together and centrifuged at 5000 rpm for 15 minutes and the O D was recorded at 645 and 663nm in Beckman DU2 spectrophotometer. The amount of chlorophyll was calculated by the formula (Witham et.al 1971). 


\section{Biochemical Analysis of Root, Stem and Leaf}

a) Electrical conductivity in the extract of root stem and leaf.

2 gram of each sample of root, stem and leaf was weighed and was homogenized in $20 \mathrm{ml}$ of conductivity water by the help of mortar and pestle separately. The homogenate was centrifuged at 2000rpm for 15 minutes. $10 \mathrm{ml}$ of supernatant of each sample was taken out separately and EC was measured by adopting the procedure.

Table 1: EC of Extract of root, stem and leaf of 15 days old seedlings grown in plain and amended soil.

\begin{tabular}{|c|c|c|c|c|}
\hline \multirow{2}{*}{$\begin{array}{c}\text { Parts of } \\
\text { seedlings }\end{array}$} & \multicolumn{4}{|c|}{ Electrical Conductivity } \\
\cline { 2 - 5 } & PS & $\begin{array}{c}\text { PS+ } \\
\text { Vermocompost }\end{array}$ & $\begin{array}{c}\text { PS+ } \\
\text { Neemcake }\end{array}$ & $\begin{array}{c}\text { PS+ } \\
\text { Urea }\end{array}$ \\
\hline Root & 1.234 & 0.977 & 1.344 & 1.555 \\
\hline Stem & 0.957 & 0.955 & 0.879 & 0.679 \\
\hline Leaf & 1.045 & 1.234 & 1.212 & 1.211 \\
\hline
\end{tabular}

\section{b) Protein content in extraction of root, stem and leaf}

Estimation of protein was done by Lowry et al. (1951). 100 $\mathrm{mg}$ of root stem and leaf of the 15 days old seedlings grown in plain soil and in the soil amended with vermicompost, neemcake and urea was homogenized separately was centrifuged at $4000 \mathrm{rpm}$ for 15 minutes.

Table 2: Protein content in extract of root, stem and leaf of 15 days old seedlings grow in plain and amended soil.

\begin{tabular}{|c|c|c|c|c|}
\hline seedlings & PS & Ps+Vermicompost & PS+Neem & PS+Urea \\
\hline Root & 0.7 & 0.4 & 0.8 & 1.2 \\
\hline stem & 2.1 & 1.2 & 1.3 & 1 \\
\hline Leaf & 0.4 & 1 & 0.6 & 0.9 \\
\hline
\end{tabular}

c) Sugar content in extract of root, stem and leaf.

Pentose and Hexose sugars of the extract of root stem and leaf of 15 days old seedlings grown in plain and amended soil.

\section{d) Chlorophyll contents of leaves}

Total chlorophyll content of leaves of 15 days old seedlings grown in plain soil and amended soil.

\section{Result and Discussion}

The electrical conductivity in the extract of root, stem and leaf shows enhanced amount in the seedling grown in the soil amended with vermicompost. Electrical conductivity is the result of sum total of the several cation and anions, amino acids and sugars.

Protein contents of the extract of root, stem and leaf of the seedlings grown in the soil amended with vermicompost and neem cake showed slightly less amount as in the extract of root, stem and leaf of seedlings grown in plain soil. Atiyeh et al. (2001a, b) indicated that combinations of pig manure vermicompost with liquid fertilizers increased the efficiency of nitrogen uptake by the plants.
Pentose and hexose sugar of the extract of root, stem and leaf of the seedling grown in the soil amended with vermicompost, neem cake and urea showed slightly less amount than in the extract of root, stem and leaf of the seedlings grown in the plain soil.

The increase of total chlorophyll in the seedlings grown in soil amended with vermicompost, neem cake and urea in the comparision to Livne (1964) observed that the loss in the chlorophyll pigment in the seedlings results in suppressed biomass due to deranged photosynthesis. Vermocompost releases most of the nitrogen in the nitrate form (Edward and Burrows 1988) the form readily available for plant uptake. Goh and Haynes (1977) reported that plant growth is generally optimized when the $\mathrm{PH}$ between 5 to 6.5 . Vermicomposts contained large concentration of nitrates, thus increasing plant growth significantly to a level comparable to that of fertilized soil in the soyabean study. Saviozzi et al.(1988) reported that organic wastes, in order to be compatible with agricultural uses and to avoid adverse effects on plant growth.

So it is therefore possible that differences in plant growth between vermicompost, neem cake and urea may not simply be a function of the differences in their nutritional content especially in the first green house study with all treatments supplied with all needed mineral nutrients. It seems probablethat there are other inputs such as increased enzymatic activity and presence of beneficial microorganism or biologically active plant growth influencing substances, that might be involved (Grappelli et al. 1987, De Brito Alvares et al. 1995, Tomati and Galli 1995).

\section{References}

[1] Atiyeh, R.M.S. Subler, C.A. Edwards and J.Metzger (1999): Growth of tomato plants in horticultural potting media amended with vermicompost. Pedobiologia 43:724-728.

[2] Derbyshire, E: Wright, D.J. and D. Boulter (1976): legumin and Vicilin, storage proteins of legume seed. Photochemistry. 15 (1): 3-24.

[3] Danieslsson, C.E (1949): Seed glubulins of graminae and Leguminosae. The Biochemical Journal. 44 (4): 387-400.

[4] Dubois, M.K., and J.K. Hemilton: P.A. Roberts and F. Smith (1951): A colorimetric method for the determination of sugar. Nature . 168:167.

[5] Edward, C.A. (1998): The use of earthworms in the breakdown and management of organic wastes. In: earthworm Ecology. CRC Press LLC, Boca Ration, p327-354.

[6] Edwards, C.A. and I. Burrows (1988): The potential of earthworm compost as plant growth media. In Edwards, C.A. and Neuhauser, E.F. (E.Ds.). Earthworm in waste and environment management. SPB Academic publishers. The netheralands 21-32.

[7] Goh. K.M. and R.J. Haynes (1977): Evaluation of potting media for commercial nursery production of container grown plants. New Zealand Journal of agricultural Research. 20:363-370. 


\section{International Journal of Science and Research (IJSR) \\ ISSN (Online): 2319-7064}

Index Copernicus Value (2013): 6.14 | Impact Factor (2015): 6.391

[8] Grappelli, A .E. Galli and U. Tomati (1987): Earthworm casting effect on agaricus bisporus fructification. Agrochimica 21: 457-462.

[9] Saviozzi, A: R. Levi- minizi and R. Riffldi (1988): Maturity evaluation of organic wastes. Bio Cycle. 29; 54-56.

[10] Symolon, H. E. schmeiz d. dillehay and a. Merrill (2004): Dietry soy sphingolipids suppress tumorigenesis and gene expression. P 1157-1161.

[11] Wolf, W.J (2012): Legumes: seed composition and structure, processing in to protein products and protein properties. United States Department of agriculture. P 291-314.

Table 3: Pentose sugar content of root stem and leaf \begin{tabular}{|l|c|c|c|c|}
\hline seedlings & PS & PS+vermicompost & PS+Neem & PS=Urea \\
\hline
\end{tabular}

\begin{tabular}{|c|c|c|c|c|}
\hline Root & 1.6 & 1.2 & 1.5 & 1.6 \\
\hline Stem & 0.6 & 1.2 & 0.5 & 0.8 \\
\hline Leaf & 1.3 & 0.5 & 1.2 & 1.2 \\
\hline
\end{tabular}

Table 4: Chlorophyll contents of Leaves.

\begin{tabular}{|c|c|c|c|}
\hline PS & PS+vermicompost & PS+ Neem & PS+ Urea \\
\hline 0.5 & 7.774 & 4.454 & 3.133 \\
\hline
\end{tabular}

\section{Author Profile}

Dr. Kumar Vimal (corresponding author) completed the Ph.D. degree in plant science in 2013 from VEER

Kunwar Singh University Ara Bihar completed ASRB NET in agriculture biotechnology in 2014. He is continuously doing Research in plant science and Guest faculty in CSIR Life Science private coaching. 